\title{
Changes in photosynthetic pigments and chlorophyll fluorescence parameters in the super-high-yielding rice hybrid Peiai64S/E32 during senescence
}

\author{
L.D. ZENG ${ }^{*, \dagger}$, Q.L. ZHANG ${ }^{*, \dagger}$, M.L. CAI ${ }^{* *}$, W.S. $\mathrm{CHOW}^{* * *}$, and C.L. $\mathrm{PENG}^{* *,+}$ \\ School of Life Science, Huizhou University, 516007 Huizhou, Guangdong Province, China* \\ Guangdong Provincial Key Laboratory of Biotechnology for Plant Development, School of Life Sciences, \\ South China Normal University, 510631 Guangzhou, China** \\ Division of Plant Sciences, Research School of Biology, College of Medicine, Biology and Environment, \\ The Australian National University, Acton, Australian Capital Territory 2601, Australia***
}

\begin{abstract}
The hybrid rice (Oryza sativa L.) cultivar Peiai64S/E32, which is a hybrid of E32 and Peiai64S, has a super high yield compared with that of its parents. Changes in photosynthetic pigments and chlorophyll (Chl) fluorescence parameters were investigated in the flag leaves during senescence. The content of $\mathrm{Chl}$ and carotenoids in the flag leaves of Peiai64S/E32 was more stable than those of their parents during senescence. Furthermore, Peiai64S/E32 had a more stable PSII activity and a lower nonphotochemical quenching and deepoxidation state than that of its parents in the later stage of senescence. These results demonstrated that Peiai64S/E32 functioned longer than its parents did during the leaf senescence and grain-filling period. This occurred because there was more excitation energy to drive photosynthetic $\mathrm{CO}_{2}$ fixation in Peiai64S/E32, as the pigments supplying the energy survived longer in the high-yielding rice compared to the parents.
\end{abstract}

Additional key words: crop; light absorption; photoprotection; photosynthesis.

\section{Introduction}

Rice (Oryza sativa L.) is one of the most important food crop species worldwide, and more than half of the global population consumes rice as a staple food (Dorward 2012). As important photosynthetic source organs of rice, leaves provide the majority of energy and organic matter for plants. The yield of rice mainly originates from photosynthesis of leaves. With the development of rice grains, the leaves enter the senescence stage (Gregersen et al. 2013). The pigments related to photosynthesis degrade rapidly during the process of leaf senescence (Zhang et al. 2019), which leads to a gradual decrease in the photosynthetic rate (Sakuraba et al. 2012).

Chl and carotenoids (Car) are two major pigments involved in photosynthesis in the leaves of higher plants (Rodríguez et al. 2016, Zhang et al. 2018). A decline of the pigment contents is usually regarded as a reliable index of leaf senescence (Zhang et al. 2019, Zheng et al. 2019).
The function of Chl is to absorb and transfer light energy, and $\mathrm{Chl}$ is an important component of the antenna complex system (Han et al. 2017). The Chl content of rice leaves decreased gradually during the process of senescence (Zhang et al. 2019). The Chl found in plants are Chl $a$ and $b$ and their roles are somewhat different. Chl $a$ and $b$ are both present in all light-harvesting complexes but the core or reaction centers contain only $\mathrm{Chl} a$. The $\mathrm{Chl} a / b$ ratio and the $\mathrm{Chl}(a+b)$ content can reflect the state of quantum capture and the utilization of the whole system (Dittami et al. 2010). The Car present in plants are normally $\beta$-Car and xanthophylls, such as violaxanthin (V), antheraxanthin (A), zeaxanthin (Z), lutein (L), and neoxanthin (N). V, A, and $\mathrm{Z}$ are interconverted during the xanthophyll cycle, which increases thermal dissipation and reduces damage by light (Demmig-Adams and Adams 1992). This cycle is one of the mechanisms in plants for protection against photoinhibition (Niyogi et al. 2001).

Chl fluorescence in plants mainly occurs because of

\footnotetext{
Received 18 November 2019, accepted 22 April 2020.

${ }^{+}$Corresponding author; phone: +86-20-85217612, fax:+86-20-85215535, e-mail: pengchl@scib.ac.cn

Abbreviations: A - antheraxanthin; Car - carotenoids; Chl - chlorophyll; DAT - days after transplanting; DES - deepoxidation state; $\mathrm{F}_{0}$ - minimal fluorescence yield of the dark-adapted state; $\mathrm{F}_{0}{ }^{\prime}-$ minimal fluorescence yield of the light-adapted state; $\mathrm{F}_{\mathrm{m}}-$ maximal fluorescence yield of the dark-adapted state; $\mathrm{F}_{\mathrm{v}} / \mathrm{F}_{\mathrm{m}}$ - maximal quantum yield of PSII photochemistry; $\mathrm{L}$ - lutein; N - neoxanthin; NPQ nonphotochemical quenching; $\mathrm{q}_{\mathrm{N}}$ - nonphotochemical quenching coefficient; $\mathrm{q}_{\mathrm{p}}$ - photochemical quenching coefficient; RCII - reaction center of PSII; V - violaxanthin; Z - zeaxanthin.

Acknowledgements: This work was funded by the National Natural Science Foundation of China (31870374 and 31570398). The study was also supported by Guangdong Province Natural Science Foundation (2017A030313167, 2015A030311023).

${ }^{\dagger}$ These authors contributed equally to this work.
} 
the reaction center of PSII. Fluorescence is closely related to photosynthesis and can provide information concerning photosynthesis (Fu et al. 2012, Murchie and Lawson 2013, Zhang et al. 2019). The value of the maximal quantum yield of PSII photochemistry $\left(\mathrm{F}_{\mathrm{v}} / \mathrm{F}_{\mathrm{m}}\right)$ in different plant leaves ranges from 0.75 to 0.85 under normal conditions (Maxwell and Johnson 2000), but it decreases significantly during the aging process (Ou et al. 2003). Moreover, $\mathrm{F}_{\mathrm{v}} / \mathrm{F}_{\mathrm{m}}$ is an important indicator of the degree of senescence. The hybrid rice (Oryza sativa L.) cultivar Peiai64S/E32 has a super high yield compared to its parents (Yuan 2000, Ou et al. 2005). This paper investigated the changes in photosynthetic pigments and chlorophyll fluorescence in the flag leaves of the super-high-yielding rice hybrid Peiai64S/E32 and its parents during senescence, and the reasons for the high yield of Peiai64S/E32 were analyzed.

\section{Materials and methods}

Plant material: Seeds of the super-high-yielding rice hybrid Peiai64S/E32 (Peiai64S×32, cv. Peiai64S/E32, HY) were supplied by the Hunan Hybrid Rice Center, and the seeds of its paternal line 'E32' (cultivar E32, Japonica rice, Fath) and its maternal line 'Peiai64S' (cultivar 64S, which simultaneously contains components of Hsien rice, Japonica rice, and Javan rice, Moth) were supplied by the Heredity Breeding Group of the South China Institute of Botany of the Chinese Academy of Sciences. The seeds were sown in an experimental field of the South China Institute of Botany; the plants were managed and fertilized in accordance with routine practices. Experiments were carried out at the later development stage: from $47 \mathrm{~d}$ after transplanting (DAT) to 84 DAT.

HPLC analysis of Car composition: Samples were taken at 13:00 h on a sunny day in the field and quickly immersed in liquid nitrogen. Fresh leaves $(0.5 \mathrm{~g})$ were ground in a mortar with a small amount of $\mathrm{CaCO}_{3}$ powder, quartz sand, and $5 \mathrm{~mL}$ of acetone. The homogenate was then centrifuged at $13,000 \times g$ at $4^{\circ} \mathrm{C}$ for $10 \mathrm{~min}$. The supernatant was subsequently filtered through a membrane with microholes (FA of $0.05 \mu \mathrm{m}$ ) and then analyzed by HPLC. The sample was then treated via a $\mathrm{C}_{18}$ chromatograph column $(5 \mu \mathrm{m}$, $210 \times 4.6 \mathrm{~mm})$ and linear gradient separation, with $10 \mu \mathrm{L}$ per sample (Waters 2695, Waters, USA). Pigment content was estimated according to the methods of Gilmore and Yamamoto (1991). The deepoxidation state (DES) was defined as $(\mathrm{Z}+0.5 \mathrm{~A}) /(\mathrm{V}+\mathrm{A}+\mathrm{Z})$.

Measurements for $\mathrm{Chl}$ fluorescence parameters: $F_{v} / F_{m}$ values need to be measured under low light condition after dark adaptation. The leaves were wrapped with wet gauze for $15 \mathrm{~min}$ in the dark. The parameters of the Chl fluorescence kinetics of the rice leaves in vitro were measured by a pulse-modulated fluorescence PAM 101/102/103 fluorometer (Heinz Walz, Effeltrich, Germany) at $25^{\circ} \mathrm{C}$. The minimal fluorescence yield of the light-adapted state $\left(\mathrm{F}_{0}{ }^{\prime}\right)$ was recorded after adaptation to the intensity of light [300 $\mu \mathrm{mol}($ photon $) \mathrm{m}^{-2} \mathrm{~s}^{-1}$. The detached leaves were dark adapted for $15 \mathrm{~min}$ before measurement, and the minimal fluorescence yield of the dark-adapted state $\left(\mathrm{F}_{0}\right)$ was measured with a low-intensity modulated beam $[1.6 \mathrm{kHz}$, $0.5 \mu \mathrm{mol}$ (photon) $\mathrm{m}^{-2} \mathrm{~s}^{-1}$. The maximal fluorescence yield of the dark-adapted state $\left(\mathrm{F}_{\mathrm{m}}\right)$ was induced by saturated light [Schott lamp KL 1500 FL 103; 6,000 $\mu$ mol(photon) $\mathrm{m}^{-2} \mathrm{~s}^{-1}, 2 \mathrm{~s}$ ] followed by treatment with a lower intensity of light [300 $\mu \mathrm{mol}\left(\right.$ photon) $\mathrm{m}^{-2} \mathrm{~s}^{-1}$ ] and with light at $100 \mathrm{kHz}$ supplied by the PAM 102 instrument to improve the ratio of signal to noise and to stabilize the output signals of fluorescence. The primary photochemical efficiency of PSII $\left[\mathrm{F}_{\mathrm{v}} / \mathrm{F}_{\mathrm{m}}=\left(\mathrm{F}_{\mathrm{m}}-\mathrm{F}_{0}\right) / \mathrm{F}_{\mathrm{m}}\right]$, the activity of PSII $\left[\mathrm{F}_{\mathrm{v}} / \mathrm{F}_{0}=\right.$ $\left.\left(\mathrm{F}_{\mathrm{m}}-\mathrm{F}_{0}\right) / \mathrm{F}_{0}\right]$, the photochemical quenching coefficient $\left(\mathrm{q}_{\mathrm{P}}\right)$ and the nonphotochemical quenching coefficient $\left(\mathrm{q}_{\mathrm{N}}\right)$ were calculated according to the methods of Schreiber et al. (1986) and Genty et al. (1990), and all the Chl fluorescence parameters were reported as relative values.

Measurement of $\mathrm{Chl} \boldsymbol{a}$ and $\boldsymbol{b}$ content: Fresh leaf material was extracted in $80 \%$ acetone at $4^{\circ} \mathrm{C}$ in the dark for $24 \mathrm{~h}$. Taking $80 \%$ acetone as a blank control, the absorption spectra of Chl at 663,645 , and $470 \mathrm{~nm}$ wavelengths were recorded using a $U V-2450$ spectrophotometer (Shimadzu, Tokyo, Japan). The total content of $\mathrm{Chl}$ and Car was subsequently measured according to the methods of Lichtenthaler (1987).

Statistical analysis: Values were expressed as means \pm standard error (SE). Statistical significance was determined by one-way or two-way analysis of variance (ANOVA) with Duncan's multiple range test using SPSS Statistics 19.0 (IBM, NY, USA). Means were considered to be significantly different at the level $p<0.05$. Data were processed by using the SigmaPlot software (version 10.0, SYSTAT Software Inc., Richmond, CA, USA).

\section{Results}

Chl and Car content: Chl is an important pigment that is a component of photosystem reaction centers and adjacent antennae. Chl $a$ is a component of the reaction centers and is a key substance in light energy transformation. The content of Chl $a, \mathrm{Chl} b$, and Car in the flag leaves declined during senescence (Table 1). Chl $a$ declined more quickly than did $\mathrm{Chl} b$, and $\mathrm{Chl}$ decreased more quickly than did Car in HY and its parents (Fig. 1). The ratio of Chl $a / b$ was nearly stable before 74 DAT, and the content of Chl $a$ declined quicker than did that of $\mathrm{Chl} b$ after 74 DAT. The results showed that $\mathrm{Chl} a / b$ and $\mathrm{Chl}(a+b)$ declined and that $\mathrm{Car} / \mathrm{Chl}$ increased in the flag leaves during senescence. $\mathrm{Car} / \mathrm{Chl}$ in the two parents was more stable before 63 DAT but later increased quickly. Car/Chl in HY increased quickly after 74 DAT. The ratio of $\beta-C a r / \Sigma X$ increased first but then decreased with the flag leaf senescence (Fig. 1C). The content of Chl and Car was stable in the HY during leaf senescence and was significantly higher than those of the parents in the later stage of leaf senescence. Table 2 showed that lines and dates have significant effect on the changes of $\mathrm{Chl}$ and Car content, and there was significant 
Table 1. Changes in the chlorophyll (Chl) and carotenoid (Car) of the flag leaves of HY rice and its parents during senescence. $\Sigma \mathrm{Car}=\beta-\mathrm{Car}+\mathrm{L}+\mathrm{N}+\mathrm{V}+\mathrm{A}+\mathrm{Z}$. A - antheraxanthin; $\mathrm{L}$ - lutein; $\mathrm{N}$ - neoxanthin; $\mathrm{V}$ - violaxanthin; $\mathrm{Z}$ - zeaxanthin. The values are the means $(n=5)$. The different letters indicate statistical significance $(p<0.05)$. Fath - paternal line of super high-yielding hybrid rice Peiai64S/E32; Moth - maternal line of super high-yielding hybrid rice Peiai64S/E32; HY - the super high-yielding hybrid rice Peiai64S/E32.

\begin{tabular}{|c|c|c|c|c|c|}
\hline \multirow[t]{2}{*}{ Content $\left[\mathrm{nmol} \mathrm{g}^{-1}(\mathrm{FM})\right]$} & \multirow[t]{2}{*}{ Line } & \multicolumn{4}{|l|}{ DAT [d] } \\
\hline & & 47 & 63 & 74 & 84 \\
\hline \multirow[t]{3}{*}{ Chl $a$} & Fath & $3,028 \pm 245^{\mathrm{a}}$ & $3,396 \pm 252^{\mathrm{a}}$ & $1,825 \pm 138^{\mathrm{a}}$ & $923 \pm 88^{b}$ \\
\hline & Moth & $2,596 \pm 231^{\mathrm{ab}}$ & $2,908 \pm 188^{\mathrm{a}}$ & $860 \pm 92^{\mathrm{b}}$ & $698 \pm 57^{c}$ \\
\hline & HY & $3,450 \pm 316^{\mathrm{a}}$ & $2,476 \pm 175^{\mathrm{b}}$ & $1,599 \pm 167^{\mathrm{a}}$ & $1,225 \pm 93^{\mathrm{a}}$ \\
\hline \multirow[t]{3}{*}{ Chl $b$} & Fath & $833 \pm 86^{a}$ & $996 \pm 84^{\mathrm{a}}$ & $568 \pm 64^{\mathrm{a}}$ & $345 \pm 37^{\mathrm{a}}$ \\
\hline & Moth & $665 \pm 67^{b}$ & $755 \pm 62^{b}$ & $227 \pm 30^{\mathrm{b}}$ & $237 \pm 35^{\mathrm{b}}$ \\
\hline & HY & $913 \pm 87^{a}$ & $651 \pm 66^{\mathrm{b}}$ & $434 \pm 37^{\mathrm{a}}$ & $387 \pm 44^{\mathrm{a}}$ \\
\hline \multirow[t]{3}{*}{$\operatorname{Chl}(a+b)$} & Fath & $3,862 \pm 245^{\mathrm{ab}}$ & $4,393 \pm 416^{\mathrm{a}}$ & $2,393 \pm 262^{\mathrm{a}}$ & $1,269 \pm 95^{b}$ \\
\hline & Moth & $3,262 \pm 264^{b}$ & $3,664 \pm 310^{\mathrm{b}}$ & $1,087 \pm 111^{\mathrm{b}}$ & $936 \pm 82^{c}$ \\
\hline & HY & $4,364 \pm 317^{\mathrm{a}}$ & $3,128 \pm 241^{\mathrm{bc}}$ & $2,034 \pm 195^{\mathrm{a}}$ & $1,612 \pm 117^{\mathrm{a}}$ \\
\hline \multirow[t]{3}{*}{$\Sigma \mathrm{Car}$} & Fath & $1,293 \pm 149^{\mathrm{ab}}$ & $784 \pm 93^{b}$ & $1,580 \pm 203^{\mathrm{a}}$ & $824 \pm 101^{b}$ \\
\hline & Moth & $1,332 \pm 146^{\mathrm{a}}$ & $1,288 \pm 103^{\mathrm{a}}$ & $699 \pm 94^{c}$ & $792 \pm 71^{b}$ \\
\hline & HY & $1,676 \pm 187^{a}$ & $1,218 \pm 102^{\mathrm{a}}$ & $1,202 \pm 123^{b}$ & $1,088 \pm 97^{\mathrm{a}}$ \\
\hline
\end{tabular}

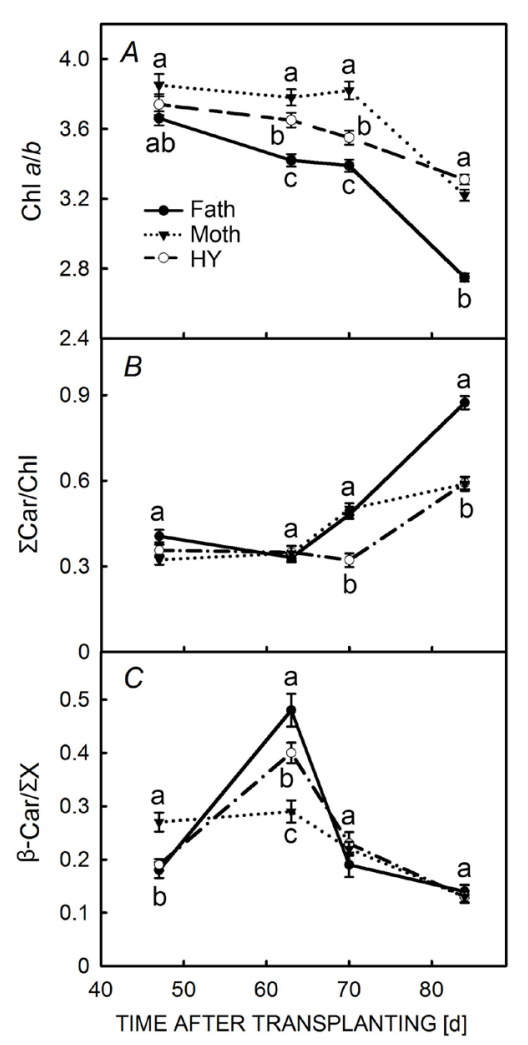

Fig. 1. Changes in chlorophyll $a / b(\mathrm{Chl} a / b)(A), \Sigma \mathrm{Car} / \mathrm{Chl}(B)$ and $\beta-\mathrm{Car} / \Sigma \mathrm{X}(C)$ of the flag leaves of $\mathrm{HY}$ rice and its parents during senescence. $\Sigma \mathrm{Car}=\beta-\mathrm{Car}+\mathrm{L}+\mathrm{N}+\mathrm{V}+\mathrm{A}+\mathrm{Z} . \Sigma \mathrm{X}=\mathrm{V}+$ $\mathrm{A}+\mathrm{Z}+\mathrm{L}+\mathrm{N}$. A - antheraxanthin; $\mathrm{L}-$ lutein; $\mathrm{N}-$ neoxanthin; $\mathrm{V}$ - violaxanthin; $\mathrm{Z}$-zeaxanthin. The values are the means $(n=5)$. The different letters indicate statistical significance $(p<0.05)$. Fathpaternal line of super high-yielding hybrid rice Peiai64S/E32; Moth - maternal line of super high-yielding hybrid rice Peiai64S/ E32; HY - the super high-yielding hybrid rice Peiai64S/E32. interaction between lines and dates.

Xanthophyll cycle sink components and Car compositions: The content of $\mathrm{A}$ and $\mathrm{Z}$ increased during flag leaf senescence, and the content of $\mathrm{V}$ decreased (Table 3 ). The content of $\mathrm{V}, \mathrm{A}$, and $\mathrm{Z}$ was the highest in $\mathrm{HY}$ at the later stage (84 DAT) of flag leaf senescence. The content of $\beta$-Car, L, and N decreased during flag leaf senescence, and they were the highest in HY at 84 DAT. Compared to those in the parents, the content of Car compounds (V, A, Z, L, N, and $\beta$-Car) in HY notably exhibited moderate parental dominance at 74 DAT and substantial parental dominance at 84 DAT. Heterosis was not obvious in the former stage of senescence. Table 2 showed that lines and dates have significant effect on the changes of xanthophyll cycle sink components (lines have no significant effect on the changes of Z) and Car compositions, and there was significant interaction between lines and dates.

Xanthophyll cycle and $\mathrm{Chl}$ fluorescence parameters: The values of $\mathrm{F}_{\mathrm{v}} / \mathrm{F}_{\mathrm{m}}$ in $\mathrm{HY}$ and its parents were stable before 74 DAT but decreased quickly after 74 DAT (Fig. $2 A$ ). The value of $\Phi_{\text {PSII }}$ in the two parents decreased quickly from 63 DAT, and this decrease was lower in HY during flag leaf senescence (Fig. 2B). $\mathrm{F}_{0}$ increased, and $\mathrm{F}_{0}^{\prime}$ declined gradually (Fig. 2C,D). The value of nonphotochemical quenching (NPQ) in the two parents decreased before 63 DAT but increased after 63 DAT. However, the value of NPQ in HY decreased before 74 DAT but increased after 74 DAT. The NPQ was lowest in HY after 74 DAT (Fig. 2E). The value of DES increased gradually with increased flag leaf senescence and was highest in the Moth plants (Fig. 2F). Lines and dates have significant effect on the changes of $F_{v} / F_{m}, \Phi_{P S I}, F_{0}, F_{0}^{\prime}, N P Q$, and DES, and there was significant interaction (except $\mathrm{F}_{0}{ }^{\prime}$ ) between lines and dates (Table 2). 
Table 2. Two-way analysis of variance of photosynthetic pigments and chlorophyll fluorescence parameters. A - antheraxanthin; Car carotenoid; Chl - chlorophyll; DES - deepoxidation state; $\mathrm{F}_{0}$ - minimal fluorescence yield of the dark-adapted state; $\mathrm{F}_{0}{ }^{\prime}-$ minimal fluorescence yield of the light-adapted state; $\mathrm{F}_{\mathrm{v}} / \mathrm{F}_{\mathrm{m}}$ - maximal quantum yield of PSII photochemistry; $\mathrm{L}$ - lutein; N - neoxanthin; NPQ nonphotochemical quenching; $\mathrm{V}$ - violaxanthin; $\mathrm{Z}$ - zeaxanthin; $\Phi_{\mathrm{PSII}}-$ effective quantum yield of PSII photochemistry. $\Sigma \mathrm{X}=\mathrm{V}+\mathrm{A}+$ $\mathrm{Z}+\mathrm{L}+\mathrm{N} . \Sigma \mathrm{Car}=\beta-\mathrm{Car}+\mathrm{L}+\mathrm{N}+\mathrm{V}+\mathrm{A}+\mathrm{Z} .{ }^{*}-p<0.05,{ }^{* *}-p<0.01, * * *-p<0.001$, ns - no significant difference at $p=0.05(n=5)$.

\begin{tabular}{|c|c|c|c|}
\hline \multirow[t]{2}{*}{ Source } & \multicolumn{3}{|l|}{$F$-value } \\
\hline & Lines & Dates & Lines $\times$ Dates \\
\hline Chl $a\left[\mathrm{nmol} \mathrm{g}^{-1}(\mathrm{FM})\right]$ & $1,295.06^{* * *}$ & $13,795.50^{* * *}$ & $570.44^{* * *}$ \\
\hline $\mathrm{Chl} b\left[\mathrm{nmol} \mathrm{g}^{-1}(\mathrm{FM})\right]$ & $64.01^{* * *}$ & $325.33^{* * *}$ & $22.56^{* * *}$ \\
\hline $\mathrm{Chl}(a+b)\left[\mathrm{nmol} \mathrm{g}^{-1}(\mathrm{FM})\right]$ & $537.52^{* * *}$ & $5,026.41^{* * *}$ & $226.24^{* * *}$ \\
\hline$\Sigma \mathrm{Car}\left[\mathrm{nmol} \mathrm{g}^{-1}(\mathrm{FM})\right]$ & $91.95^{* * *}$ & $157.48^{* * *}$ & $54.75^{* * *}$ \\
\hline Chl $a / b$ & $7.97^{* *}$ & $11.10^{* * *}$ & $3.70^{*}$ \\
\hline$\Sigma \mathrm{Car} / \mathrm{Chl}$ & $11.06^{* * *}$ & $304.42^{* * *}$ & $8.16^{* * *}$ \\
\hline$\beta-\operatorname{Car} / \Sigma \mathrm{X}$ & $51.05^{* * *}$ & $358.82^{* * *}$ & $52.74^{* * *}$ \\
\hline $\mathrm{V}\left[\mathrm{nmol} \mathrm{g}{ }^{-1}(\mathrm{FM})\right]$ & $55.23^{* * *}$ & $1,074.06^{* * *}$ & $30.63^{* * *}$ \\
\hline $\mathrm{A}\left[\mathrm{nmol} \mathrm{g}^{-1}(\mathrm{FM})\right]$ & $23.05^{* * *}$ & $136.53^{* * *}$ & $52.66^{* * *}$ \\
\hline $\mathrm{Z}\left[\mathrm{nmol} \mathrm{g}^{-1}(\mathrm{FM})\right]$ & $2.85^{\mathrm{ns}}$ & $287.63^{* * *}$ & $36.04^{* * *}$ \\
\hline $\mathrm{VAZ}\left[\mathrm{nmol} \mathrm{g}{ }^{-1}(\mathrm{FM})\right]$ & $23.68^{* * *}$ & $22.41^{* * *}$ & $39.47^{* * *}$ \\
\hline$\beta$-Car $\left[\mathrm{nmol} \mathrm{g}^{-1}(\mathrm{FM})\right]$ & $23.88^{* * *}$ & $295.73^{* * *}$ & $29.04^{* * *}$ \\
\hline $\mathrm{L}\left[\mathrm{nmol} \mathrm{g}^{-1}(\mathrm{FM})\right]$ & $202.09^{* * *}$ & $178.23^{* * *}$ & $102.35^{* * *}$ \\
\hline $\mathrm{N}\left[\mathrm{nmol} \mathrm{g}{ }^{-1}(\mathrm{FM})\right]$ & $56.96^{* * *}$ & $196.17^{* * *}$ & $13.29^{* * *}$ \\
\hline $\mathrm{F}_{\mathrm{v}} / \mathrm{F}_{\mathrm{m}}$ & $49.86^{* * *}$ & $13,599.71^{* * *}$ & $44.97^{* * *}$ \\
\hline$\Phi_{\mathrm{PSII}}$ & $5.03^{*}$ & $5.97^{* *}$ & $3.91^{* *}$ \\
\hline $\mathrm{F}_{0}$ & $125.72^{* * *}$ & $300.05^{* * *}$ & $43.68^{* * *}$ \\
\hline $\mathrm{F}_{0}{ }^{\prime}$ & $66.75^{* * *}$ & $352.67^{* * *}$ & $0.98^{\mathrm{ns}}$ \\
\hline NPQ & $22.36^{* * *}$ & $346.99^{* * *}$ & $23.31^{* * *}$ \\
\hline DES & $125.42^{* * *}$ & $4,417.24^{* * * *}$ & $24.01^{* * *}$ \\
\hline
\end{tabular}

\section{Discussion}

Chl is an important structural substance through which plants capture light energy. A high content of Chl is the basis of high photosynthetic rate. The content of $\mathrm{Chl}$ in the flag leaves decreased gradually during senescence (47-84 DAT). HY exhibited hybrid dominance at 47 DAT (flowering period) and at 84 DAT (the fully ripe stage). The Chl content was more stable in the HY than that in the parents during senescence. The higher Chl content is beneficial for increasing rice yield (Zhang et al. 2019). Car play two important roles in photosynthesis: Car can capture light energy and have the capability of providing photoprotection. Car can transfer absorbed excited energy to $\mathrm{Chl}$ and can also remove singlet oxygen to prevent photosynthetic organisms from damage (Domonkos et al. 2013, Niyogi and Truong 2013, Hashimoto et al. 2016). Two-way ANOVA showed that lines and dates have significant effect on the changes of $\mathrm{Chl}$ and Car content (Table 2). The content of Car in the parents fluctuated greatly during the aging process, but the content in HY was stable. The content in the HY was the highest in the later stage (84 DAT) of senescence. The results of the $\mathrm{Chl}$ and Car showed that super-high-yielding rice not only had enough auxiliary pigments to capture light but also had a stronger light protection capacity, which helps avoid photooxidation caused by free radicals (Croce et al.
2007). This protection is also helpful for keeping the photosynthetic apparatus stable.

The function of the PSII reaction center irreversibly decreased (declines in $\mathrm{F}_{\mathrm{v}} / \mathrm{F}_{\mathrm{m}}, \Phi_{\mathrm{PSII}}$, and $\mathrm{F}_{0}{ }^{\prime}$ ) with increasing flag leaf senescence. $F_{0}$ represents the fluorescence level when PSII is completely open. An increase in the value of $\mathrm{F}_{0}$ means that the reaction center of PSII (RCII) was destroyed or the separation between photosynthetic pigments and RCII caused irreversible denaturation (Calatayud et al. 2006, Gorbe and Calatayud 2012). PSII activity can be significantly affected by lines and dates (Table 2). $\mathrm{F}_{0}$ increased in both HY and its parents during flag leaf senescence, and all kinds of photosynthetic pigments gradually degraded, which showed that RCII was destroyed and that the photosynthetic function gradually diminished. However, the values of $F_{v} / F_{m}$ (no significant difference) and $\Phi_{\mathrm{PSII}}$ were the highest in HY during the senescence of the flag leaves, which showed that HY may have a more stable reaction centers than did its parents. One of its high yield-related characteristics may be the ability to maintain the stability of the photosynthetic apparatus and maintain longer a more efficient functional stage.

Dates have significant effect on the changes of $\mathrm{V}, \mathrm{A}$, and $\mathrm{Z}$ content (Table 2). During the senescence of rice leaves, the content of $\mathrm{V}$ decreased gradually, and the content of $\mathrm{A}$ and $\mathrm{Z}$ increased continuously (Table 3 ). V is converted to $\mathrm{A}$ and $\mathrm{Z}$ under the conditions of excess 
Table 3. Changes in the carotenoid (Car) components of the flag leaves of HY rice and its parents during senescence. A - antheraxanthin; $\mathrm{L}$ - lutein; $\mathrm{N}$ - neoxanthin; V - violaxanthin; $\mathrm{Z}$ - zeaxanthin. The values are the means $(n=5)$. The different letters indicate statistical significance $(p<0.05)$. Fath - paternal line of the super-high-yielding rice hybrid Peiai64S/E32; Moth - maternal line of the super-highyielding rice hybrid Peiai64S/E32; HY - the super-high-yielding rice hybrid Peiai64S/E32.

\begin{tabular}{|c|c|c|c|c|c|}
\hline & Line & $\begin{array}{l}\text { DAT [d] } \\
47\end{array}$ & 63 & 74 & 84 \\
\hline $\begin{array}{l}\mathrm{V}\left[\mathrm{nmol} \mathrm{g}^{-1}(\mathrm{FM})\right] \\
(\% \text { of } \mathrm{VAZ} \text { pool })\end{array}$ & $\begin{array}{l}\text { Fath } \\
\text { (Fath) } \\
\text { Moth } \\
\text { (Moth) } \\
\text { HY } \\
\text { (HY) }\end{array}$ & $\begin{array}{l}195.4 \pm 8.2^{\mathrm{b}} \\
\left(64.7 \pm 7.7^{\mathrm{y}}\right) \\
200.4 \pm 12.2^{\mathrm{b}} \\
\left(64.9 \pm 4.1^{\mathrm{y}}\right) \\
262.6 \pm 12.1^{\mathrm{a}} \\
\left(72.8 \pm 7.7^{\mathrm{x}}\right)\end{array}$ & $\begin{array}{l}182.6 \pm 11.5^{\mathrm{a}} \\
\left(63.4 \pm 5.2^{\mathrm{x}}\right) \\
144.9 \pm 9.3^{\mathrm{b}} \\
\left(51.7 \pm 7.2^{\mathrm{y}}\right) \\
143.6 \pm 11.5^{\mathrm{b}} \\
\left(60.1 \pm 9.3^{\mathrm{x}}\right)\end{array}$ & $\begin{array}{l}85.3 \pm 9.2^{\mathrm{a}} \\
\left(19.1 \pm 2.3^{\mathrm{x}}\right) \\
37.8 \pm 3.5^{\mathrm{b}} \\
\left(16.7 \pm 2.1^{\mathrm{x}}\right) \\
69.1 \pm 5.3^{\mathrm{ab}} \\
\left(19.9 \pm 1.3^{\mathrm{x}}\right)\end{array}$ & $\begin{array}{l}50.7 \pm 7.3^{\mathrm{ab}} \\
\left(22.5 \pm 3.8^{\mathrm{x}}\right) \\
36.3 \pm 5.5^{\mathrm{c}} \\
\left(12.9 \pm 1.2^{\mathrm{z}}\right) \\
62.0 \pm 4.2^{\mathrm{a}} \\
\left(17.0 \pm 1.3^{\mathrm{y}}\right)\end{array}$ \\
\hline $\begin{array}{l}\mathrm{A}\left[\mathrm{nmol} \mathrm{g}^{-1}(\mathrm{FM})\right] \\
(\% \text { of } \mathrm{VAZ} \text { pool })\end{array}$ & $\begin{array}{l}\text { Fath } \\
\text { (Fath) } \\
\text { Moth } \\
\text { (Moth) } \\
\text { HY } \\
\text { (HY) }\end{array}$ & $\begin{array}{l}30.3 \pm 2.4^{\mathrm{a}} \\
\left(10.0 \pm 1.2^{\mathrm{x}}\right) \\
33.7 \pm 2.3^{\mathrm{a}} \\
\left(10.9 \pm 0.9^{\mathrm{x}}\right) \\
38.5 \pm 4.7^{\mathrm{a}} \\
\left(10.6 \pm 1.6^{\mathrm{x}}\right)\end{array}$ & $\begin{array}{l}39.1 \pm 3.2^{\mathrm{ab}} \\
\left(13.6 \pm 1.1^{\mathrm{y}}\right) \\
48.0 \pm 4.4^{\mathrm{a}} \\
\left(17.1 \pm 1.4^{\mathrm{x}}\right) \\
39.9 \pm 4.3^{\mathrm{ab}} \\
\left(16.7 \pm 1.2^{\mathrm{x}}\right)\end{array}$ & $\begin{array}{l}102.3 \pm 8.9^{\mathrm{a}} \\
\left(22.9 \pm 3.3^{\mathrm{x}}\right) \\
45.7 \pm 3.8^{\mathrm{c}} \\
\left(20.2 \pm 1.3^{\mathrm{x}}\right) \\
73.0 \pm 5.3^{\mathrm{b}} \\
\left(21.1 \pm 2.2^{\mathrm{x}}\right)\end{array}$ & $\begin{array}{l}44.4 \pm 4.1^{\mathrm{c}} \\
\left(19.7 \pm 2.4^{\mathrm{xy}}\right) \\
57.7 \pm 7.4^{\mathrm{b}} \\
\left(20.4 \pm 1.6^{\mathrm{xy}}\right) \\
84.0 \pm 9.5^{\mathrm{a}} \\
\left(23.1 \pm 2.1^{\mathrm{x}}\right)\end{array}$ \\
\hline $\begin{array}{l}\mathrm{Z}\left[\mathrm{nmol} \mathrm{g}^{-1}(\mathrm{FM})\right] \\
(\% \text { of } \mathrm{VAZ} \text { pool })\end{array}$ & $\begin{array}{l}\text { Fath } \\
\text { (Fath) } \\
\text { Moth } \\
\text { (Moth) } \\
\text { HY } \\
\text { (HY) }\end{array}$ & $\begin{array}{l}76.2 \pm 6.3^{\mathrm{a}} \\
\left(25.2 \pm 2.4^{\mathrm{x}}\right) \\
74.5 \pm 5.8^{\mathrm{a}} \\
\left(24.1 \pm 2.3^{\mathrm{x}}\right) \\
59.7 \pm 8.1^{\mathrm{b}} \\
\left(16.6 \pm 1.5^{\mathrm{y}}\right)\end{array}$ & $\begin{array}{l}66.1 \pm 5.1^{\mathrm{b}} \\
\left(22.9 \pm 2.6^{\mathrm{y}}\right) \\
87.2 \pm 7.7^{\mathrm{a}} \\
\left(31.1 \pm 4.1^{\mathrm{x}}\right) \\
55.2 \pm 6.7^{\mathrm{bc}} \\
\left(23.1 \pm 2.4^{\mathrm{y}}\right)\end{array}$ & $\begin{array}{l}259.3 \pm 28.8^{\mathrm{a}} \\
\left(58.0 \pm 6.4^{\mathrm{x}}\right) \\
142.6 \pm 14.7^{\mathrm{c}} \\
\left(63.1 \pm 7.3^{\mathrm{x}}\right) \\
204.9 \pm 18.9^{\mathrm{b}} \\
\left(59.0 \pm 4.1^{\mathrm{x}}\right)\end{array}$ & $\begin{array}{l}129.8 \pm 9.1^{\mathrm{c}} \\
\left(57.7 \pm 8.0^{\mathrm{x}}\right) \\
188.0 \pm 21.0^{\mathrm{ab}} \\
\left(66.6 \pm 6.3^{\mathrm{x}}\right) \\
217.6 \pm 26.4^{\mathrm{a}} \\
\left(59.8 \pm 7.3^{\mathrm{x}}\right)\end{array}$ \\
\hline VAZ pool $\left[\mathrm{nmol} \mathrm{g}^{-1}(\mathrm{FM})\right]$ & $\begin{array}{l}\text { Fath } \\
\text { Moth } \\
\text { HY }\end{array}$ & $\begin{array}{l}302.0 \pm 28.3^{\mathrm{ab}} \\
308.6 \pm 23.3^{\mathrm{ab}} \\
360.8 \pm 42.9^{\mathrm{a}}\end{array}$ & $\begin{array}{l}287.9 \pm 31.1^{\mathrm{a}} \\
280.2 \pm 27.3^{\mathrm{a}} \\
238.8 \pm 28.4^{\mathrm{ab}}\end{array}$ & $\begin{array}{l}446.9 \pm 35.1^{\mathrm{a}} \\
226.1 \pm 28.2^{\mathrm{c}} \\
347.1 \pm 26.7^{\mathrm{b}}\end{array}$ & $\begin{array}{l}224.9 \pm 19.5^{\mathrm{c}} \\
282.1 \pm 22.3^{\mathrm{b}} \\
363.7 \pm 38.4^{\mathrm{a}}\end{array}$ \\
\hline$\beta$-Car $\left[\mathrm{nmol} \mathrm{g}^{-1}(\mathrm{FM})\right]$ & $\begin{array}{l}\text { Fath } \\
\text { Moth } \\
\text { HY }\end{array}$ & $\begin{array}{l}193.7 \pm 22.3^{\mathrm{b}} \\
287.2 \pm 33.2^{\mathrm{a}} \\
243.7 \pm 27.2^{\mathrm{ab}}\end{array}$ & $\begin{array}{l}255.0 \pm 22.7^{\mathrm{b}} \\
288.3 \pm 31.2^{\mathrm{b}} \\
385.9 \pm 42.3^{\mathrm{a}}\end{array}$ & $\begin{array}{l}191.3 \pm 21.2^{\mathrm{a}} \\
95.1 \pm 11.5^{\mathrm{b}} \\
159.4 \pm 18.5^{\mathrm{a}}\end{array}$ & $\begin{array}{l}100.4 \pm 14.3^{\mathrm{ab}} \\
94.2 \pm 8.4^{\mathrm{b}} \\
124.4 \pm 13.6^{\mathrm{a}}\end{array}$ \\
\hline $\mathrm{L}\left[\mathrm{nmol} \mathrm{g}^{-1}(\mathrm{FM})\right]$ & $\begin{array}{l}\text { Fath } \\
\text { Moth } \\
\text { HY }\end{array}$ & $\begin{array}{l}585.0 \pm 60.2^{\mathrm{b}} \\
592.9 \pm 55.6^{\mathrm{b}} \\
766.1 \pm 81.1^{\mathrm{a}}\end{array}$ & $\begin{array}{l}677.8 \pm 63.4^{\mathrm{a}} \\
595.7 \pm 68.3^{\mathrm{ab}} \\
600.7 \pm 56.6^{\mathrm{ab}}\end{array}$ & $\begin{array}{l}821.4 \pm 81.1^{\mathrm{a}} \\
328.6 \pm 26.7^{\mathrm{c}} \\
591.1 \pm 65.9^{\mathrm{b}}\end{array}$ & $\begin{array}{l}444.2 \pm 50.7^{\mathrm{ab}} \\
362.4 \pm 32.6^{\mathrm{b}} \\
504.8 \pm 62.8^{\mathrm{a}}\end{array}$ \\
\hline $\mathrm{N}\left[\mathrm{nmol} \mathrm{g}^{-1}(\mathrm{FM})\right]$ & $\begin{array}{l}\text { Fath } \\
\text { Moth } \\
\text { HY }\end{array}$ & $\begin{array}{l}212.7 \pm 17.0^{\mathrm{a}} \\
143.6 \pm 11.2^{\mathrm{b}} \\
163.9 \pm 19.8^{\mathrm{b}}\end{array}$ & $\begin{array}{l}164.1 \pm 12.5^{\mathrm{a}} \\
123.8 \pm 16.8^{\mathrm{ab}} \\
135.4 \pm 15.3^{\mathrm{ab}}\end{array}$ & $\begin{array}{l}120.6 \pm 12.4^{\mathrm{a}} \\
50.1 \pm 4.3^{\mathrm{c}} \\
104.7 \pm 9.8^{\mathrm{ab}}\end{array}$ & $\begin{array}{l}54.6 \pm 7.4^{\mathrm{b}} \\
53.9 \pm 6.5^{\mathrm{b}} \\
95.1 \pm 11.3^{\mathrm{a}}\end{array}$ \\
\hline
\end{tabular}

excitation energy by xanthophyll cycle, and the process of the xanthophyll cycle increases thermal dissipation and reduces light damage (Demmig-Adams and Adams 1992, Li et al. 2018). Previous results showed that there is a photo-carbon imbalance in the process of rice leaf senescence, which leads to excess excitation energy (Yu et al. 2020). V degraded during the senescence stage, which might occur because $\mathrm{V}$ in the flag leaves was destroyed by photooxidation during senescence, and $\mathrm{V}$ gradually transformed into $\mathrm{A}$ and $\mathrm{Z}$, causing a decrease in $\mathrm{V}$ and an increase in $\mathrm{A}$ and $\mathrm{Z}$ (Table 3), and the trend of $A$ and $Z$ was consistent with NPQ. NPQ is positively correlated with the content of $\mathrm{A}$ and $\mathrm{Z}$ (Li et al. 2018), and in the mutants with xanthophyll cycle blocked, NPQ decreased significantly compared with the wild type ( $\mathrm{Li}$ et al. 2016). It showed that xanthophyll cycle can play a role in the photoprotection of leaves. The content of $\mathrm{A}$ and $\mathrm{Z}$ increased steadily in the HY, was stable during the senescence stage, and was the highest during the late senescence stage (84 DAT), suggesting that the HY had better photoprotection.

NPQ reflects the heat dissipation level, and through NPQ, plants can dissipate excitation energy and decrease the formation of oxidative stress (Ruban 2016). The relatively high $\Phi_{\mathrm{PSII}}$ and relatively low NPQ in HY at 74 DAT showed that the HY could maintain high PSII activity in the later stage of senescence. The decline in $\mathrm{F}_{0}{ }^{\prime}$ was considered to reflect the heat dissipation of the PSII antennae depending on the xanthophyll cycle (Khoroshyy et al. 2018). The gradual decrease in $\mathrm{F}_{0}^{\prime}$ in $\mathrm{HY}$ and its parents was in line with the increase in $\mathrm{Z}$ and DES, which further showed that antenna heat dissipation, depending on 


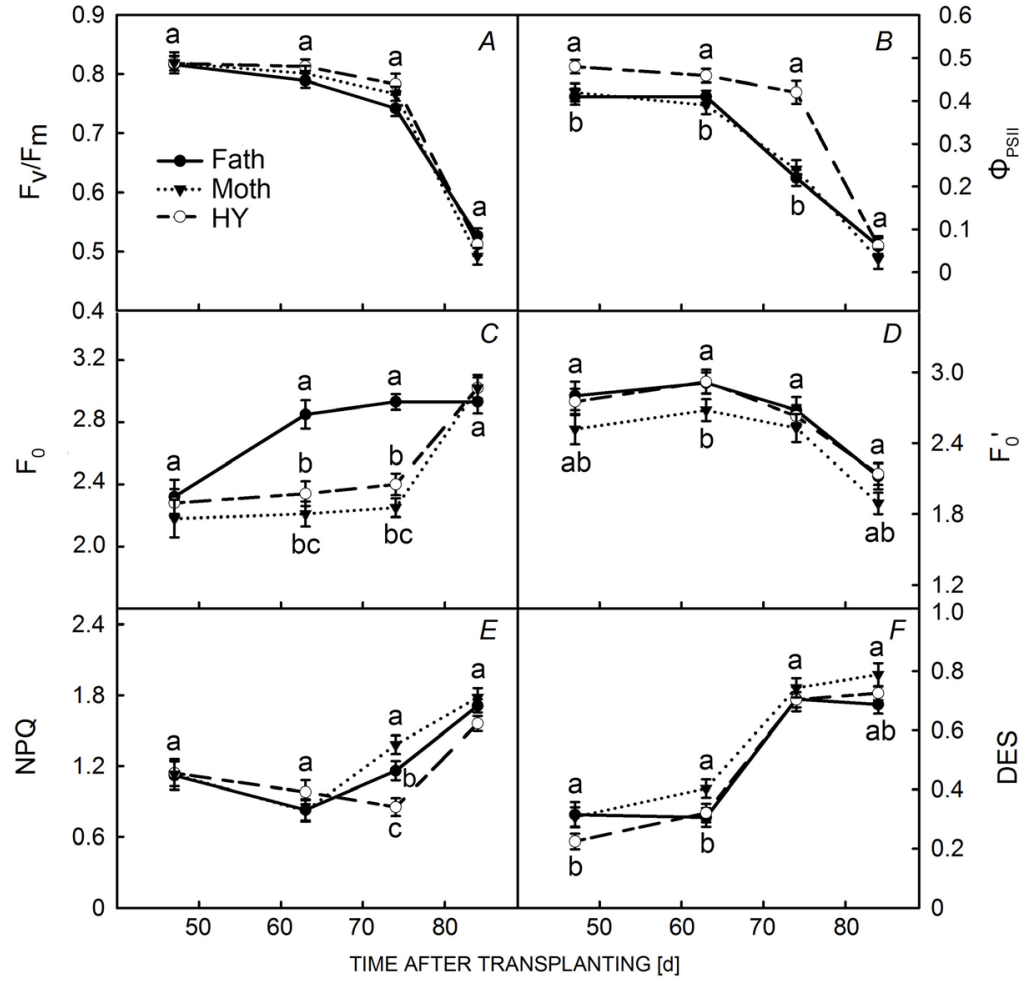

Fig. 2. Changes in the maximal quantum yield of PSII photochemistry $\left(\mathrm{F}_{\mathrm{v}} / \mathrm{F}_{\mathrm{m}}\right)(A)$, effective quantum yield of PSII photochemistry $\left(\Phi_{\text {PSII }}\right)(B)$, minimal fluorescence yield of the dark-adapted state $\left(\mathrm{F}_{0}\right)(C)$, minimal fluorescence yield of the light-adapted state $\left(\mathrm{F}_{0}{ }^{\prime}\right)(D)$, nonphotochemical quenching $(\mathrm{NPQ})(E)$, and deepoxidation state $(\mathrm{DES})(F)$ in the flag leaves of the super-highyielding rice hybrid Peiai64S/E32 and its parents during senescence. The values are the means $(n=5)$. The different letters indicate statistical significance $(p<0.05)$. Fath - paternal line of the super-high-yielding rice hybrid Peiai64S/E32; Moth - maternal line of the super-high-yielding rice hybrid Peiai64S/E32; HY - the super-highyielding rice hybrid Peiai64S/E32. the xanthophyll cycle, increased during senescence. The PSII activity was higher and more stable in HY than that in the two parents. The results of this study demonstrated that HY functions longer than do its parents during leaf senescence. The ratio of excitation energy distributed to NPQ was lesser in HY than that in its parents during senescence, and there was more excitation energy to supply photosynthetic $\mathrm{CO}_{2}$ fixation. This may be one of the physiological mechanisms of photosynthesis for the high yield advantage of $\mathrm{HY}$.

\section{References}

Calatayud A., Roca D., Martínez P.F.: Spatial-temporal variations in rose leaves under water stress conditions studied by chlorophyll fluorescence imaging. - Plant Physiol. Bioch. 44: 564-573, 2006.

Croce R., Mozzo M., Morosinotto T. et al.: Singlet and triplet state transitions of carotenoids in the antenna complexes of higher-plant photosystem I. - Biochemistry-US 46: 38463855, 2007.

Demmig-Adams B., Adams III W.W.: Photoprotection and other responses of plants to high light stress. - Annu. Rev. Plant Phys. 43: 599-626, 1992.

Dittami S.M., Michel G., Collén J. et al.: Chlorophyll-binding proteins revisited - a multigenic family of light-harvesting and stress proteins from a brown algal perspective. - BMC Evol. Biol. 10: 365, 2010.

Domonkos I., Kis M., Gombos Z., Ughy B.: Carotenoids, versatile components of oxygenic photosynthesis. - Prog. Lipid Res. 52: 539-561, 2013.

Dorward A.: The short- and medium-term impacts of rises in staple food prices. - Food Secur. 4: 633-645, 2012.

Fu W., Li P., Wu Y.: Effects of different light intensities on chlorophyll fluorescence characteristics and yield in lettuce. -
Sci. Hortic.-Amsterdam 135: 45-51, 2012.

Genty B., Harbinson J., Briantais J.M., Baker N.R.: The relationship between non-photochemical quenching of chlorophyll fluorescence and the rate of photosystem II photochemistry in leaves. - Photosynth. Res. 25: 249-257, 1990.

Gilmore A.M., Yamamoto H.Y.: Resolution of lutein and zeaxanthin using a non-endcapped, lightly carbon loaded $\mathrm{C}_{18}$ high performance liquid chromatographic column. J. Chromatogr. A 543: 137-145, 1991.

Gorbe E., Calatayud A.: Applications of chlorophyll fluorescence imaging technique in horticultural research: a review. - Sci. Hortic.-Amsterdam 138: 24-35, 2012.

Gregersen P.L., Culetic A., Boschian L., Krupinska K.: Plant senescence and crop productivity. - Plant Mol. Biol. 82: 603622, 2013

Han P.P., Shen S.G., Guo R.J. et al.: The regulation of photosynthetic pigments in terrestrial Nostoc flagelliforme in response to different light colors. - Algal Res. 25: 128-135, 2017.

Hashimoto H., Uragami C., Cogdell R.J.: Carotenoids and photosynthesis. - In: Stange C. (ed.): Carotenoids in Nature. Subcellular Biochemistry. Vol. 79. Pp. 111-139. Springer, Cham 2016.

Khoroshyy P., Bína D., Gardian Z. et al.: Quenching of chlorophyll triplet states by carotenoids in algal lightharvesting complexes related to fucoxanthin-chlorophyll protein. - Photosynth. Res. 135: 213-225, 2018.

Li L., Gu W., Li J. et al.: Exogenously applied spermidine alleviates photosynthetic inhibition under drought stress in maize (Zea mays L.) seedlings associated with changes in endogenous polyamines and phytohormones. - Plant Physiol. Bioch. 129: 35-55, 2018.

Li Z., Peers G., Dent R.M. et al.: Evolution of an atypical deepoxidase for photoprotection in the green lineage. - Nat. Plants 2: 16140, 2016.

Lichtenthaler H.K.: Chlorophylls and carotenoids: Pigments 
of photosynthetic biomembranes. - Method. Enzymol. 148: 350-382, 1987.

Maxwell K., Johnson G.N.: Chlorophyll fluorescence a practical guide. - J. Exp. Bot. 51: 659-668, 2000.

Murchie E.H., Lawson T.: Chlorophyll fluorescence analysis: a guide to good practice and understanding some new applications. - J. Exp. Bot. 64: 3983-3998, 2013.

Niyogi K.K., Shih C., Chow W.S. et al.: Photoprotection in a zeaxanthin- and lutein-deficient double mutant of Arabidopsis. - Photosynth. Res. 67: 139-145, 2001.

Niyogi K.K., Truong T.B.: Evolution of flexible non-photochemical quenching mechanisms that regulate light harvesting in oxygenic photosynthesis. - Curr. Opin. Plant Biol. 16: 307-314, 2013.

Ou Z.Y., Peng C.L., Lin G.Z. et al.: Relationship between PS II excitation pressure and content of Rubisco large subunit or small subunit in flag leaf of super high-yielding hybrid rice. Acta Bot. Sin. 8: 929-935, 2003.

Ou Z.Y., Peng C.L., Lin G.Z.: [Photosynthetic characteristics in flag leaves of super high-yielding hybrid rice Peiai64S/E32 and its parents grown in the field.] - Acta Agron. Sin. 31: 209213, 2005. [In Chinese]

Rodríguez F., Garrido J.L., Sobrino C. et al.: Divinyl chlorophyll a in the marine eukaryotic protist Alexandrium ostenfeldii (Dinophyceae). - Environ. Microbiol. 18: 627-643, 2016.
Ruban A.V.: Non-photochemical chlorophyll fluorescence quenching: mechanism and effectiveness in protection against photodamage. - Plant Physiol. 170: 1903-1916, 2016.

Sakuraba Y., Balazadeh S., Tanaka R. et al.: Overproduction of Chl $b$ retards senescence through transcriptional reprogramming in Arabidopsis. - Plant Cell Physiol. 53: 505-517, 2012.

Schreiber U., Schliwa U., Bilger W.: Continuous recording of photochemical and non-photochemical quenching of chlorophyll fluorescence quenching with a new type of modulation fluorometer. - Photosynth. Res. 10: 51-62, 1986.

Yu L., Zhang Q., Lu L. et al.: The role of ascorbic acid in rice leaf senescence and photo-carbon imbalance. - Funct. Plant Biol. 47: 263-278, 2020.

Yuan L.P.: [Hybrid rice breeding for super high yield.] - Hybrid Rice 15: 31-33, 2000. [In Chinese]

Zhang Q.L., Ding W.Q., Wei Y.X. et al.: Exogenous ascorbic acid delayed leaf senescence of early flowering rice mutant FTL10. - Photosynthetica 57: 960-966, 2019.

Zhang Q.L., Wei Y.X., Peng C.L.: Effects of endogenous ascorbic acid on resistance to high-temperature stress in excised rice leaves. - Photosynthetica 56: 1453-1458, 2018.

Zheng X.T., Zhang X.H., Wang Y.Z. et al.: Identification of a $G L D H$-overexpressing Arabidopsis mutant and its responses to high-light stress. - Photosynthetica 57: 332-341, 2019.

(C) The authors. This is an open access article distributed under the terms of the Creative Commons BY-NC-ND Licence. 